Delft University of Technology

\title{
Comparative performance between C4.5 and Naive Bayes classifiers in predicting student academic performance in a Virtual Learning Environment
}

Azizah, Erwina Nurul; Pujianto, Utomo; Nugraha, Eki; Darusalam

DOI

10.1109/ICEAT.2018.8693928

Publication date

2019

Document Version

Accepted author manuscript

Published in

2018 4th International Conference on Education and Technology, ICET 2018

\section{Citation (APA)}

Azizah, E. N., Pujianto, U., Nugraha, E., \& Darusalam (2019). Comparative performance between C4.5 and Naive Bayes classifiers in predicting student academic performance in a Virtual Learning Environment. In 2018 4th International Conference on Education and Technology, ICET 2018 (pp. 18-22). [8693928] Institute of Electrical and Electronics Engineers (IEEE). https://doi.org/10.1109/ICEAT.2018.8693928 Important note

To cite this publication, please use the final published version (if applicable).

Please check the document version above.

\footnotetext{
Copyright

Other than for strictly personal use, it is not permitted to download, forward or distribute the text or part of it, without the consent of the author(s) and/or copyright holder(s), unless the work is under an open content license such as Creative Commons.

Takedown policy

Please contact us and provide details if you believe this document breaches copyrights.

We will remove access to the work immediately and investigate your claim.
} 


\section{Comparative performance between $\mathrm{C} 4.5$ and Naive Bayes classifiers in predicting student academic performance in a Virtual Learning Environment}

\author{
$1^{\text {st }}$ Erwina Nurul Azizah \\ Department of Electrical Engineering \\ Universitas Negeri Malang \\ Malang, Indonesia \\ erawina25@gmail.com \\ $3^{\text {rd }}$ Eki Nugraha \\ Department of Computer Science \\ Universitas Pendidikan Indonesia \\ Bandung, Indonesia \\ ekinugraha@upi.edu
}

\author{
$2^{\text {nd }}$ Utomo Pujianto \\ Department of Electrical Engineering \\ Universitas Negeri Malang \\ Malang, Indonesia \\ utomo.pujianto.ft@um.ac.id \\ $4^{\text {th }}$ Darusalam \\ Faculty of Technology, Policy and Management \\ Delft University of Technology \\ Delft, Netherlands \\ d.darusalam@tudelft.nl
}

\begin{abstract}
People now trying to maximizing function of Virtual Learning Environment. Virtual Learning Environment, not only as a place to help learning system but now has become a place of learning itself. But with the change of the learning system, teacher now have difficulty to monitor the activity of the student and the learning material. Although there is data that is considered capable become a benchmark for students and the interaction with Virtual Learning Activity. This paper will make a data prediction using Naïve bayes and C4.5 Algorithm using the Web History data and the sum of webpage interaction of the students in Virtual Learning Environment.
\end{abstract}

Keywords-Data Mining, Prediction, Naive Bayes, C4.5

\section{INTRODUCTION}

Virtual learning environment is a dimension created to get information, and this information is information related to education. In the Virtual learning environment, students not only actively use, but also as actors who build the learning space [1]. Virtual learning environment are mostly used only as supporting learning systems, such as academic information system for example. In fact, in other countries the Virtual learning environment has been used as an alternative lecture for several universities [2]. But from the Virtual learning environment, we are not able to monitor student behavior during the learning period. We know in education not only the value of the learning subjects is important, but also the enthusiasm and attitude of students in the learning period. To be able to measure the activity of a student in a virtual learning environment, we can see a list of the virtual learning environment web pages that students have accessed and their interactions. In this study, the prediction method will be used to see whether activities on the Virtual learning Activity web page can be used as a reference in graduating students.

Virtual Learning Environment doesn't refer to website related to the theme of education. According to [3] Virtual Learning Environment is a social environment that is centered around education-themed interaction, where students are not only active, but also as actors, they help build the scope. Virtual Learning Environment certainly require computers and the internet as a major component in the learning system. The purpose of developing the Virtual Learning Environment is to maximize learning using the internet. The internet really provides a profitable potential to make flexible access to connecting communication between students and teachers. The Virtual Learning Environment provides the opportunity for teachers to make learning materials quickly without requiring additional work, because the internet function can be used in the Virtual Learning Environment.

Many classification algorithms are used to predict student graduation. One of them is the $\mathrm{C} 4.5$ algorithm which produces an accuracy of $87.5 \%$ [4]. There are also predictions with the Neural Network Algorithm and optimized with Particle Swarm, this method produces accuracy of $78.26 \%$ [5]. Evaluation of academic performance predicted by the Naive Bayes algorithm has a high accuracy rate of $82.8 \%$ [6]. Using two algorithms, C4.5 and CART. The C4.5 algorithm looks better with $85.61 \%$ accuracy [7]. From the algorithm described, it looks C4.5 and also Naive Bayes has a high level of accuracy. Therefore this research will use these two algorithms.

\section{METHODS}

\section{A. Research Design}

The design of the research will be carried out as in Fig. 1.

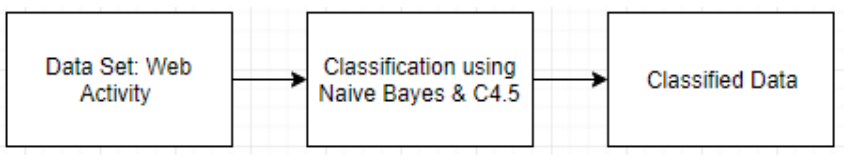

Fig. 1. Research design

Naive Bayes Classifiation is an simple classification algorithm which is able to calculate the probability, By calculating the frequency and combination of entries in the dataset. This algorithm uses Bayes theorem, assuming all attributes are independent variable values [9].

$$
P(H \mid X)=\frac{P(X \mid H) P(H)}{P(X)}
$$

The Formula Above make $\mathrm{H}$ is a Class and $\mathrm{X}$ is the Attribute of data. $\mathrm{P}(\mathrm{H})$ is a prior probability of $\mathrm{H}$, and $\mathrm{P}(\mathrm{X})$ is the prior probability of $\mathrm{X}$ Attribute. 
Naive Bayes is the most efficient Algorithm, which the complexity of $\mathrm{O}(t n)$ for classification induction of dataset with $t$ and $n$ variabel. As well as complexity of $\mathrm{O}(c n)$ to classify new data,$c$ is the number of classes.

The main advantage of Naive Bayes is its ease of construction, without the need to make difficult iterative parameter schemes. In addition, Naive Bayes is also strong in issues that are irrelevant and attributes [10].

The C4.5 algorithm was presented in 1993 by Ross Quinlan, the goal is as a better method than ID3. To solve problems regarding ID3 weaknesses that are difficult to use for large data, C4.5 have "Information Gain" function. Where not only makes a new ratio, but also measures it [11].

The Gain Ratio C4.5 formula is as follows:

$$
\begin{gathered}
\operatorname{GainRatio}(p, T)=\frac{\operatorname{Gain}(p, T)}{\operatorname{SplitInfo}(p, T)} \\
\operatorname{Splitinfo}(p, \text { test })=-\sum_{j=1}^{n}\left(\frac{j}{p}\right) \times \log \left(p^{\prime}\left(\frac{j}{p}\right)\right)
\end{gathered}
$$

$P^{\prime}(j / p)$ is the proportion of elements in p position. Take values from-j. Unlike entropy, the definition above does not depend on the distribution in different classes.

\section{B. Research Data}

The data is from The Open University England, in the form of an anonymus record of student learning activities in interacting with virtual learning environment [12]. The dataset used is grouped into 7 attributes, where one attribute is the class to be predicted. Explanation of the attributes to be used is as follows.

TABLE I. VARIABLE DESCRIPTION

\begin{tabular}{|l|c|c|}
\hline \multicolumn{1}{|c|}{ Name } & Description & Attribute Type \\
\hline kategorial_region & $\begin{array}{c}\text { Province origin of } \\
\text { students }\end{array}$ & Varchar \\
\hline highest_education & Student's last education & Varchar \\
\hline kategorial_credit & $\begin{array}{c}\text { Credit taken by } \\
\text { students }\end{array}$ & Range numeric \\
\hline disability & Student disability & Boolean \\
\hline kategorial_web & $\begin{array}{c}\text { Number of web pages } \\
\text { accessed }\end{array}$ & Numeric \\
\hline kategori_klik & $\begin{array}{r}\text { Number of clicks on } \\
\text { the web page }\end{array}$ & Numeric \\
\hline Final_result & $\begin{array}{c}\text { The end result whether } \\
\text { students graduate or } \\
\text { not }\end{array}$ & Boolean \\
\hline
\end{tabular}

To facilitate the mining process, the data that has already been converted becomes categorical that can be processed by the instrument. Data that needs to be categorized is "kategorial_region", "kategorial_credit". Here is a series of data that has been processed.
TABLE II. KATEGORIAL_REGION DATA

\begin{tabular}{|c|c|c|}
\hline No & Label & Count \\
\hline 1 & Another Country & 4288 \\
\hline 2 & Middle Region & 4746 \\
\hline 3 & North Region & 3794 \\
\hline 4 & South Region & 4172 \\
\hline
\end{tabular}
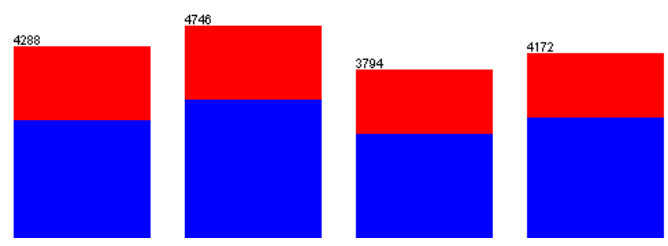

Fig. 2. Kategorial_Region

Table II and fig. 2 shows the categorical data student region at UK. Another country label refer to nearest country like Scotland and Belgium.

TABLE III. HIGHEST_EDUCATION DATA

\begin{tabular}{|c|c|c|}
\hline No & Label & Count \\
\hline 1 & A Level or Equivalent & 7558 \\
\hline 2 & HE Qualification & 2470 \\
\hline 3 & Lower Than A Level & 6675 \\
\hline 4 & No Formal quals & 166 \\
\hline 5 & Post Graduate Qualification & 131 \\
\hline
\end{tabular}
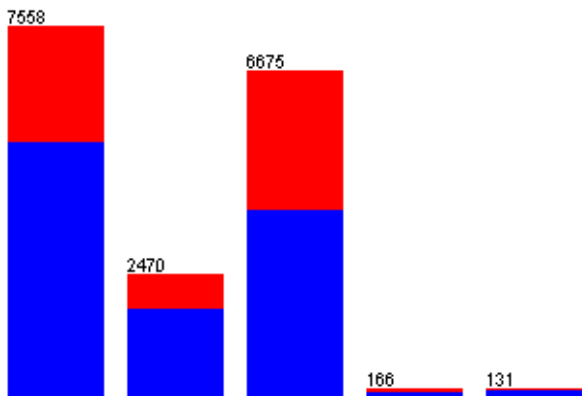

Fig. 3. Kategorial_Region

Table III and fig. 3 shows the categorial data of student degree. The UK has five educational qualifications.

TABLE IV. KATEGORIAL_CREDIT DATA

\begin{tabular}{|c|c|c|}
\hline No & Label & Count \\
\hline 1 & 100 to 150 & 3319 \\
\hline 2 & 50 to 100 & 10908 \\
\hline 3 & Above 150 & 496 \\
\hline 4 & Below 50 & 2277 \\
\hline
\end{tabular}


TABLE VII. KATEGORIAL_KLIKDATA

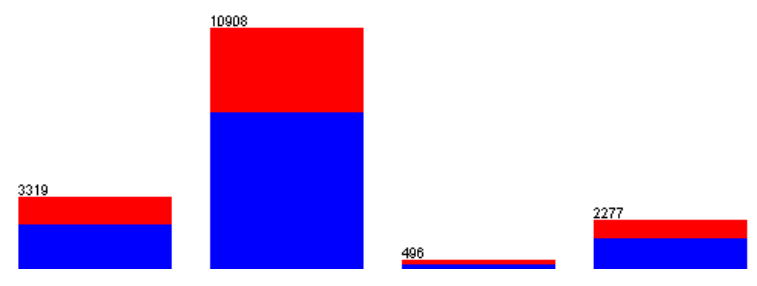

Fig. 4. Kategorial_Credit

Table IV and fig. 4 shows the categorical data of student credit. Categories divided into 4 with a maximum value of 150.

TABLE V. DISABILITY DATA

\begin{tabular}{|c|c|c|}
\hline No & Label & Count \\
\hline 1 & N & 15561 \\
\hline 2 & Y & 1439 \\
\hline
\end{tabular}

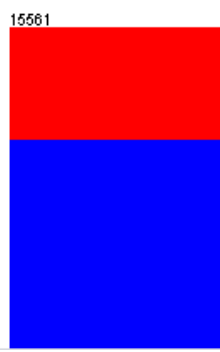

Fig. 5. Disability

Table $\mathrm{V}$ and fig. 5 shows the shows that students have physical disabilities or not.

TABLE VI. KATEGORIAL_WEB DATA

\begin{tabular}{|c|c|c|}
\hline No & Label & Count \\
\hline 1 & 1000 to 2000 & 1215 \\
\hline 2 & Under 1000 & 15731 \\
\hline 3 & Above 2000 & 54 \\
\hline
\end{tabular}

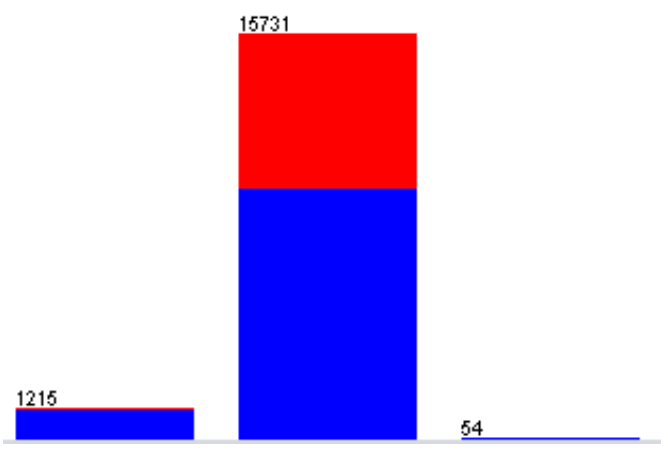

Fig. 6. Kategorial_web

Table VI and fig. 6 shows the categorical data of accumulated web pages accessed by students for each subject.

\begin{tabular}{|c|c|c|}
\hline No & Label & Count \\
\hline 1 & 8000 to 16000 & 143 \\
\hline 2 & under 8000 & 16847 \\
\hline 3 & Above 16000 & 10 \\
\hline
\end{tabular}

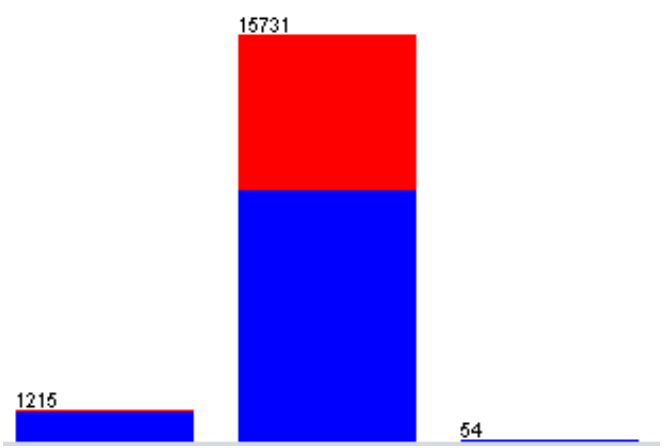

Fig. 7. Kategorial_klik

Table VII and fig. 7 shows the categorical data of accumulated click from students for each subject.

TABLE VIII. FINAL_RESUlt DATA

\begin{tabular}{|c|c|c|}
\hline No & Label & Count \\
\hline 1 & Pass & 10926 \\
\hline 2 & Fail & 6074 \\
\hline
\end{tabular}
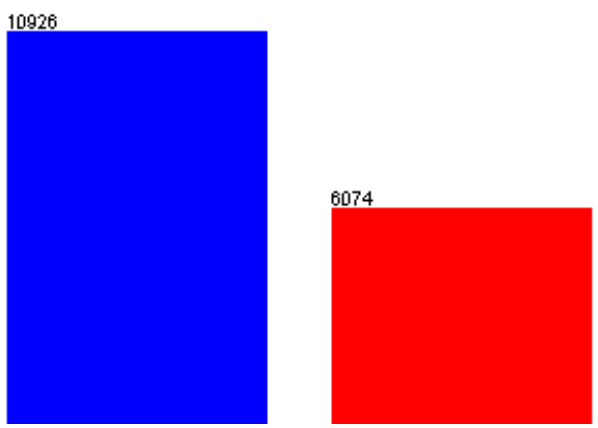

Fig. 8. Final_result

Table VIII and fig. 8 shows information whether graduating or not form their respective subjects.

\section{Evaluation}

From the data collected, there are a total of 17,000 data that are ready to be processed. We uses 10 Fold-Cross Validation for performance evaluation. The 10 Fold-Cross Validation is one of the $\mathrm{K}$ fold that is recommended for selecting the best model because it tends to provide estimates of accuracy that are less biased than the usual Cross Validation. The evaluation that will be carried out to test accuracy is confusion matrix. To find accuracy, precision, and recall using confusion matrix, the following formula is used.

$$
\text { Accurasy }=\frac{T P+T N}{T P+T N+F N+F P}
$$




$$
\begin{gathered}
\text { Precision }=\frac{T P}{F P+T P} \\
\text { Recall }=\frac{T P}{F N+T P}
\end{gathered}
$$

Where the description of the formula is as follows.

- TP : True Positive, the correct amount of positive predictive data.

- FP : False Positive, the wrong number of positive predictive data.

- FN : False Negative, Incorrect negative prediction data.

- TN : True Negative, correct negative prediction data.

\section{RESULTS AND DISCUSSION}

\section{A. Nä̈ve Baves classifier performance}

Training data was calculated and taken 1700 data sets to see the performance of the prediction of the algorithm. The results of the algorithm performance are as follows.

TABLE IX. Classification Result

\begin{tabular}{|l|r|r|}
\hline Correctly Classified Instances & 1084 & $63.7647 \%$ \\
\hline Incorrectly Classified Instances & 616 & $36.2353 \%$ \\
\hline Kappa statistic & 0.0468 & \\
\hline Mean absolute error & 0.4344 & \\
\hline Root mean squared error & 0.4679 & \\
\hline Relative absolute error & 94.0971 & \\
\hline & $\%$ & \\
\hline Root relative squared error & $\begin{array}{r}\text { \% } \\
\text { M }\end{array}$ & \\
\hline
\end{tabular}

TABLE X. CONFUSION MATRIX NAÏVE BAYES

\begin{tabular}{|c|c|c|c|c|}
\hline inst\# & actual & predicted & error & prediction \\
\hline 1 & 2:Fail & 2:Fail & & 0.517 \\
\hline 2 & 1:Pass & $1:$ Pass & & 0.953 \\
\hline 3 & 1:Рass & 1:Разs & & 0.686 \\
\hline 4 & 2:Fail & $1:$ Pass & + & 0.548 \\
\hline 5 & 1:Рass & $1:$ Pass & & 0.686 \\
\hline 6 & 2:Fail & 1:Pass & + & 0.635 \\
\hline 7 & 1:Разs & 1:Pass & & 0.663 \\
\hline 8 & 1:Pass & 1:Pass & & 0.668 \\
\hline 9 & 1:Pass & $1:$ Pass & & 0.643 \\
\hline 10 & 2:Fail & 1:Рass & + & 0.517 \\
\hline 11 & 1:Pass & 1:Pass & & 0.69 \\
\hline 12 & 1:Pass & $1:$ Pass & & 0.686 \\
\hline 13 & 1:Рass & $1:$ Рass & & 0.548 \\
\hline 14 & 1:Рass & 1:Рass & & 0.579 \\
\hline 15 & 1:Pass & 1:Рass & & 0.64 \\
\hline
\end{tabular}

\begin{tabular}{|c|c|c|}
\hline $\mathbf{a}$ & $\mathbf{b}$ & \\
\hline 1037 & 40 & $\mathbf{a}=$ Pass \\
\hline 576 & 47 & $\mathbf{b}=$ Fail \\
\hline
\end{tabular}

Fig. 9. Comparison of Actual Data with Naïve bayes predictions

\section{B. C4.5 classifier performance}

TABLE XI. CONFUSION MATRIX NAÏVE BAYES

\begin{tabular}{|l|r|r|}
\hline Correctly Classified Instances & 1081 & $63.5882 \%$ \\
\hline Incorrectly Classified Instances & 619 & $36.4118 \%$ \\
\hline Kappa statistic & 0.0232 & \\
\hline Mean absolute error & 0.4353 & \\
\hline Root mean squared error & 0.4689 & \\
\hline Relative absolute error & $94.2885 \%$ & \\
\hline Root relative squared error & $97.2894 \%$ & \\
\hline
\end{tabular}

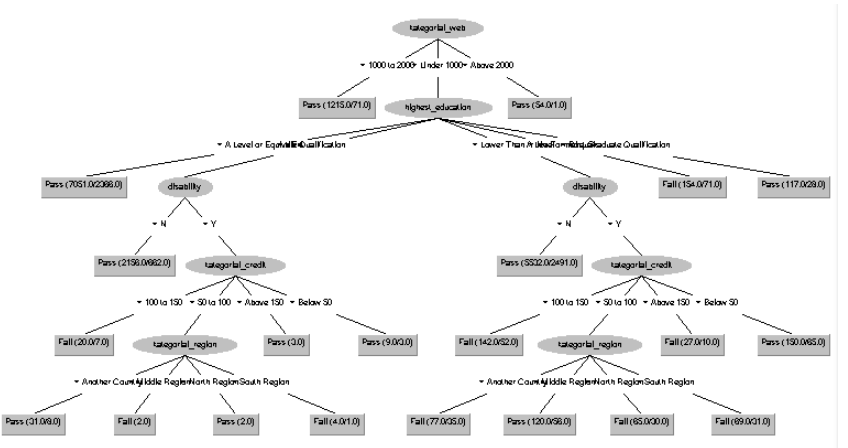

Fig. 10. C4.5 Tree generated from the training data

TABLE XII. CONFUSION MATRIX C4.5

\begin{tabular}{|c|c|c|}
\hline $\mathbf{a}$ & $\mathbf{b}$ & \\
\hline 1059 & 18 & $\mathbf{a}=$ Pass \\
\hline 601 & 22 & $\mathbf{b}=$ Fail \\
\hline
\end{tabular}




\begin{tabular}{|c|c|c|c|c|}
\hline inst\# & actual & predicted & error & prediction \\
\hline 1 & 2:Fail & 2:Fail & & 0.536 \\
\hline 2 & $1:$ Рass & 1:Разs & & 0.939 \\
\hline 3 & 1:Pass & 1:Рass & & 0.691 \\
\hline 4 & 2:Fail & $1:$ Рass & + & 0.549 \\
\hline 5 & $1:$ Pass & 1:Рass & & 0.691 \\
\hline 6 & 2:Fail & 1:Рass & + & 0.669 \\
\hline 7 & $1:$ Pass & 1:Разs & & 0.669 \\
\hline 8 & 1:Pass & 1:Разs & & 0.669 \\
\hline 9 & $1:$ Pass & $1:$ Рass & & 0.669 \\
\hline 10 & 2:Fail & 2:Fail & & 0.554 \\
\hline 11 & $1:$ Pass & 1:Pass & & 0.669 \\
\hline 12 & 1:Рass & 1:Разs & & 0.691 \\
\hline 13 & 1:Pass & 1:Рass & & 0.549 \\
\hline 14 & $1:$ Рass & $1:$ Разs & & 0.669 \\
\hline 15 & 1:Pass & 1:Рass & & 0.669 \\
\hline
\end{tabular}

Fig. 11. Comparison of actual and predictive data $\mathrm{C} 4.5$

\section{Equations}

The results of the two algorithm's confusion matrix are calculated Accuracy, Precision and Recall.

TABLE XIII. COMPARISON OF ACCURATION, PRECISION AND RECALL

\begin{tabular}{|c|c|c|}
\hline Comparison & Naive Bayes & C4.5 \\
\hline Accurasy & $63,8 \%$ & $63,6 \%$ \\
\hline Presisi & $64,3 \%$ & $63,8 \%$ \\
\hline Recall & $96,3 \%$ & $98,3 \%$ \\
\hline
\end{tabular}

\section{CONCLUSION}

From the data that has been processed using two algorithms. The results obtained, both algorithms have almost the same level of accuracy. The accuracy of Naive Bayes is superior to $63.8 \%$ even though the results from $\mathrm{C} 4.5$ only differ $0.2 \%$ from the accuracy of Naive Bayes. Even so, Recall from C4.5 Algorithm is better with a value of $98.3 \%$. From the results of the C4.5 decision tree we know that web pages are an important factor in student graduation, therefore these variables can be used as supporting variables for the value of students in the Virtual Learning Environment. Concerns about the trees formed, it was seen that students who go to the website in 1000-2000 times were categorized as students who passed the lecture. This data can be used as proof that students' VLE activities are able to be used as a reference whether students can graduate or not.

\section{REFERENCES}

[1] Dillenbourg, Pierre, Daniel Schneider, and Paraskevi Synteta. "Virtual learning environments." 3rd Hellenic Conference" Information \& Communication Technologies in Education". Kastaniotis Editions, Greece, 2002.

[2] Distance Education and Virtual Learning Environments." The University of Edinburgh, The University of Edinburgh, 8 Sept. 2015, www.ed.ac.uk/records-management/data-protection/guidancepolicies/distance-education.

[3] Kamagi, David Hartanto, and Seng Hansun. "Implementasi Data Mining dengan Algoritma C4. 5 untuk Memprediksi Tingkat Kelulusan Mahasiswa." vol. VI 1 (2014): 15-20.

[4] Kusumawati, Dewi, Wing Wahyu Winarno, and M. Rudyanto Arief. "Prediksi Kelulusan Mahasiswa Menggunakan Metode Neural Network dan Particle Swarm Optimization." SEMNASTEKNOMEDIA ONLINE 3.1 (2015): 3-8.

[5] Nugroho, Yuda Septian. "Data Mining Menggunakan Algoritma Naive Bayes Untuk Klasifikasi Kelulusan Mahasiswa Universitas Dian Nuswantoro." Dian Nuswantoro Fakultas Ilmu Komputer Skripsi (2014).

[6] Rahmayuni, Indri. "Perbandingan Performansi Algoritma C4. 5 dan Cart Dalam Klasifiksi Data Nilai Mahasiswa Prodi Teknik komputer POLITEKNIK NEGERI PADANG." Jurnal TeknoIf2.1 (2014).

[7] Dillenbourg, Pierre, Daniel Schneider, and Paraskevi Synteta. "Virtual learning environments." 3rd Hellenic Conference" Information \& Communication Technologies in Education". Kastaniotis Editions, Greece, 2002.

[8] D. T. Larose, "Data Mining Methods and Models," p. 385, 2007.

[9] Patil, Tina R., and S. S. Sherekar. "Performance analysis of Naive Bayes and J48 classification algorithm for data classification." International journal of computer science and applications 6.2 (2013): 256-261.

[10] Soria, Daniele, et al. "A 'non-parametric'version of the naive Bayes classifier." Knowledge-Based Systems 24.6 (2011): 775-784.

[11] Hssina, Badr, et al. "A comparative study of decision tree ID3 and C4. 5." International Journal of Advanced Computer Science and Applications 4.2 (2014).

[12] Kuzilek, Jakub, Martin Hlosta, and Zdenek Zdrahal. "Open university learning analytics dataset." Scientific data 4 (2017): 170171. 